DOI: http://dx.doi.org/10.18524/1810-4215.2018.31.144687

\title{
PRELIMINARY RESULTS OF INTERFEROMETRIC OBSERVATIONS OF THE QUIET SUN AT THE FREQUENCIES 8 - 32 MHZ
}

\author{
V.A. Shepelev ${ }^{1}$, V. N. Melnik ${ }^{1}$, R.V. Vashchishin ${ }^{2}$ \\ ${ }^{1}$ Institute of Radio Astronomy, Kharkiv, Ukraine \\ ${ }^{2}$ Gravimetrical Observatory of IGP, Poltava, Ukraine
}

\begin{abstract}
We studied a radio emission of the quiet Sun at decameter wavelengths to determine its angular dimensions. Observations were conducted using interferometers composed of antenna sections of the UTR-2 radio telescope. A number of interferometers with baselines of 225 to $1400 \mathrm{~m}$, oriented along the meridian, operated at two frequencies of 20 and $25 \mathrm{MHz}$ with a bandwidth $250 \mathrm{kHz}$. We used them to estimate a shape of a source brightness distribution. To measure the angular size of the Sun in a wide frequency band of $8-32 \mathrm{MHz}$ another set of interferometers was used. It consisted of two pairs of the interferometers with the baselines of 225 and $450 \mathrm{~m}$ elongated both along the parallel and the meridian. They used digital wideband receivers operating at the frequencies of 8 to $32 \mathrm{MHz}$ to record received signals. There was some sporadic solar activity during observational campaign in March-April 2015 that complicated determination of parameters of the quiet Sun radiation. A large number of radio frequency interference also noted. To mitigate their influence we applied a few data cleaning algorithms. The use of the algorithms in spectral strips with a low level of interferences in periods free from powerful sporadic solar radiation allowed us to make estimation of the angular size of the quiet Sun in two orthogonal directions at some separate frequencies in the range of 20 to $32 \mathrm{MHz}$. Calculation of the dimensions was performed in an assumption of Gaussian radio brightness distribution of the source. Our estimates of the quiet Sun sizes agree well with the data of other authors. The simplicity and convenience of determining the angular size using the data obtained with two interferometers with different baselines are noted. Continuation such study will allow to extend the frequency range down to the lowest frequencies where observations from the Earth's surface are possible and give us a possibility to study how the angular size of the quiet Sun depend on a phase of solar activity. This study will allow us to construct a model of solar corona at distances of 1.5-3 solar radii directly from the radio observations and to find out how the effective temperature of the Sun changes with the frequency.
\end{abstract}

Key words: quiet Sun, angular diameter, interferometer, decameter range.

АБСТРАКТ. Проведено дослідження радіовипромінювання спокійного Сонця на декаметрових хвилях 3 метою визначення його кутових розмірів. Спостереження проводилися за допомогою інтерферометрів, що складались із секцій антени радіотелескопу УТР-2. Одна низка інтерферометрів з базами від 225 до 1400 м, орієнтованими вздовж меридіана, працювала на двох частотах 20 і 25 МГц з шириною смуги 250 кГц. Вона використовувалася для оцінки форми розподілу яскравості джерела. Для вимірювання кутових розмірів у широкому діапазоні частот застосовано іншу групу, що складалася 3 двох пар інтерферометрів 3 базами 225 і 450 м, розташованими як уздовж паралелі, так і вздовж меридіана. Для реєстрації випромінювання в них використано цифрові широкосмугові приймачі, що працюють в діапазоні частот від 8 до 32 МГц. У спостереженнях, проведених в березні-квітні 2015 року, спостерігалися прояви спорадичної активності, які ускладнювали визначення параметрів випромінювання спокійного Сонця. Також зазначалася велика кількість радіозавад штучного походження. Для усунення їх впливу використовувалися кілька алгоритмів очищення даних. Застосування цих алгоритмів на ділянках спектра 3 малою кількістю завад в періоди, вільні від потужного спорадичного випромінювання, дозволило зробити попередні оцінки кутових розмірів спокійного Сонця в двох ортогональних напрямках на низці частот від 20 до 32 МГц. Визначення розмірів проведено у наближенні гаусового розподілу радіояскравості джерела. Отримані оцінки розмірів спокійного Сонця добре збігаються 3 даними інших авторів. Відзначено простоту і зручність визначення кутового розміру за даними двох інтерферометрів 3 довільними базами. Продовження подібних досліджень дозволить розширити частотний діапазон до найнижчих частот, на яких можливе проведення спостережень $з$ поверхні Землі, вивчити залежність кутових розмірів спокійного Сонця від фази його активності. Це дозволить також побудувати модель корони на відстанях 1.5-3 радіусу Сонця безпосередньо з радіоспостережень, знайти, як змінюється з частотою ефективна температура Сонця.

Ключові слова: спокійне Сонце, кутовий діаметр, інтерферометр, декаметровий діапазон.

\section{Introduction}

Radio emission of the quiet Sun was studied in a wide range of wavelengths, from millimeter to decameter ones. However, observations were not very frequent at the long wavelengths and only at some separate frequencies. One 
of the reasons is that a flux density of the solar radio emission decrease with wavelength with spectral index $\alpha>2$ in decameter range and flux value become less than $1000 \mathrm{Jy}$. At the same time, the radio emission of the galactic background increases with wavelength and exceeds significantly the radiation of the quiet Sun at decameter wavelengths. This requires using of antennas with a large effective area for the observations. It is of particular interest to determine how parameters of the quiet Sun depend on the wavelength, so these antennae and a backend facilities have to be sufficiently broadband. Besides, they must have a high dynamic range because of a significant level of RFI at the decameter wavelengths. The UTR-2 radio telescope (Braude et al., 1978) allows carrying out such investigations. Nowadays this radio telescope is equipped with broadband digital spectral polarimeters DSPZ (Zakharenko et al., 2016) with a capability to conduct observations at frequencies of 8 to $33 \mathrm{MHz}$ simultaneously. Determination of the solar size dependence on frequency is quite important for construction of models of physical processes underlying generation of the coronal radio emission. As it is well known angular sizes of radio Sun do not differ noticeably from its optical size down to short meters. At the same time the first observations (Aubier et al., 1971) showed that the size of the quiet Sun at frequencies of 29 and $36 \mathrm{MHz}$ is noticeably larger than the optical one and increases with decreasing frequency. Some other observations were carried out from time to time and only at some separate frequencies not lower than $19 \mathrm{MHz}$. We present preliminary results of observations with the UTR2 radio telescope to determine angular sizes of the quiet Sun in the broadband range of the decameter wavelengths.

\section{Observations and results}

The angular size of a radio source can be determined by scanning with a beam of a radio telescope. In this case an output signal is a convolution of brightness distribution of the source with an antenna pattern. If the angular size of the source significantly exceeds a beam width, one can easily find the true size of the object from the width of an output response. In the case of comparable sizes it is necessary to take into account the antenna smoothing, which increases the response width in comparison with the true size. For example, width of the UTR-2 radio telescope beam at $25 \mathrm{MHz}$ equals $25^{\prime}$ and it is comparable with the angular diameter of the quiet Sun at this frequency, which is approximately equal to $1^{\circ}$ as measured by Abranin and Bazelyan (1986). Unfortunately, the UTR-2 as well as other antenna arrays used in low-frequency radio astronomy has antenna pattern with appreciable level of side lobes. Moreover, correlation radiometers, which are used to eliminate an influence of the galactic background, result in alternating-sign view of the side lobes. Hence, twodimensional pattern of side lobes of such antenna is quite complicated and changes notably with beam orientation that complicates accounting of antenna smoothing.

In the scanning method the size of the source are determined by width of the antenna response. An alternative method is an interferometer one, according to which, an angular size of an object can be calculated based on amplitudes of response of interferometers with different base- lines. The antenna of the UTR-2 radio telescope has Tshape view and consists of two rectangular arrays oriented in the north-south and the east-west directions. Each array consists of a number of sections with a distance between their centers $225 \mathrm{~m}$. It allows forming a number of interferometers with different lengths and direction of their baselines. Ability of such interferometers to measure the angular size are illustrated in Fig. 1, where the calculated dependence of normalized visibility function $\gamma_{\mathrm{n}}$ on a length of the baseline $L$ at $25 \mathrm{MHz}$ is shown. Calculations were made for sources with different diameters with Gaussian radio brightness distribution, located at a declination of $22^{\circ}$. It is obvious, that the interferometers with the baseline of $225 \mathrm{~m}$ formed by the nearest sections and also with the baselines of 450 and $675 \mathrm{~m}$ can be used to determine the angular diameter of the quiet Sun.

Observations of the quiet Sun with such interferometers were made in May, 2014 (Melnik et al., 2018) with multichannel receivers (Rashkovsky et al., 2012), which are usually used in observations with the URAN interferometer network (Megn et al., 1997). Experimental data $\gamma(L)$ were close to calculated dependencies of a source with Gaussian brightness distribution that allowed to determine the angular diameter of the Sun using values of a correlation coefficient $\gamma_{1}$ and $\gamma_{2}$, determined only at two baselines $L_{1}$ and $L_{2}$, according to expression:

$$
\theta=\frac{2 \lambda \sqrt{\ln (2)}}{\pi} \sqrt{\frac{\ln \left(\gamma_{1} / \gamma_{2}\right)}{\left(L_{2}^{2}-L_{1}^{2}\right)}}
$$

Technique of the observations and calibrations of the interferometers for such measurements is described by Shepelev (2015). Basic restriction of the receiver used in the observations is an ability to operate only at two discrete frequencies with a bandwidth $250 \mathrm{kHz}$ that limits a range and sensitivity of the observations.

To study the possibility of determining parameters of the quiet Sun radio emission in a wide frequencies range, we observe this radio source since 31 March to 5 April, 2015. The DSPZ wideband spectral polarimeters operating in the range $8-32 \mathrm{MHz}$ were used as receivers. Each

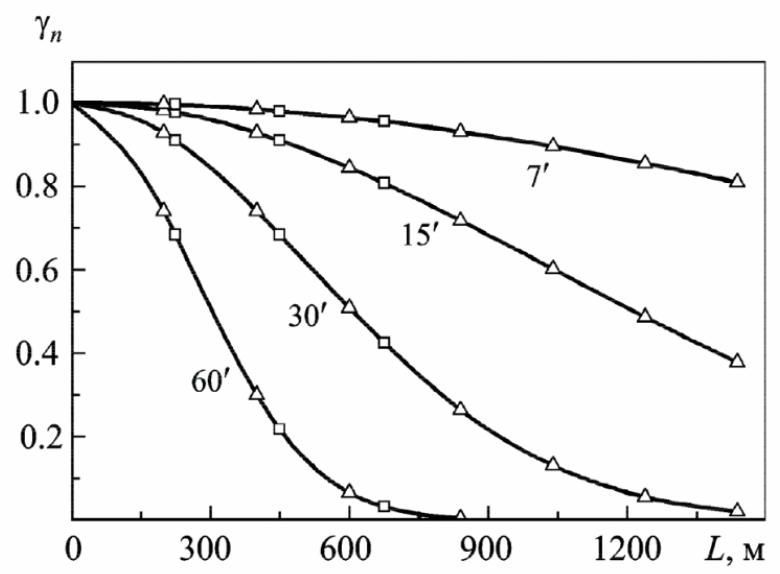

Figure 1: Dependence of normalized visibility function on a baseline and an angular size of a source. Squares mark the baselines shaped by sections of the EW antenna, triangles - by sections of the NS antenna 


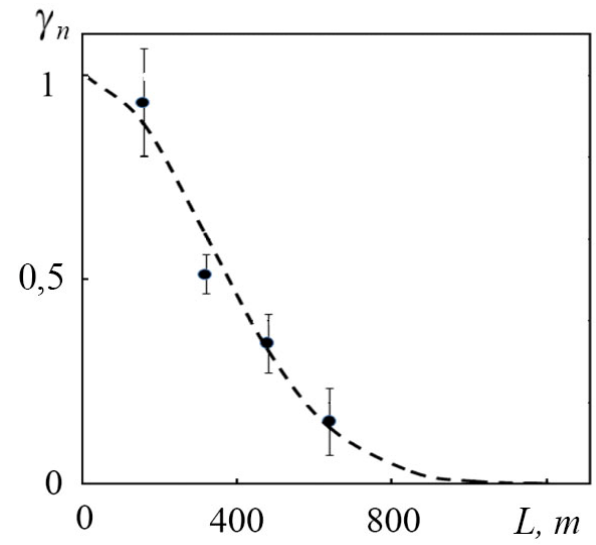

Figure 2: The experimental values of normalized visibility function versus a baseline length at frequency of $20 \mathrm{MHz}$

receiver forms at its output a complex dynamic cross spectrum that is dependence of a covariance of two input signals on frequency and time. Four receivers were connected to outputs of the sections of the north-south and east-west arrays of the UTR-2 radio telescope, forming two interferometers with the baselines of 225 and $450 \mathrm{~m}$ oriented along a meridian, and two similar interferometers oriented along a parallel. This configuration of the equipment allows determining the angular size of the quiet Sun radiation in the equatorial and polar directions in the entire frequency range of the radio telescope using the visibility function, measured on two different baselines. To determine a shape of the dependence using observations on a larger number of baselines we applied two four-channel URAN's receivers with operation frequencies 20 and $25 \mathrm{MHz}$ connected to the sections of the north-south antenna. Observations with these interferometers showed that the experimental dependences $\gamma(L)$ were close to the calculated responses from a source with a Gaussian brightness distribution (see Fig. 2) and reaffirmed admissibility of applying a technique of determination of the size from responses of two broadband interferometers according to (1).

Note that at the beginning of April a declination of the Sun is about $6^{\circ}$, therefore projections of the interferometer baselines are noticeably shorter than distances between the sections of the north-south antenna. For the same reason, the low position of the Sun, there was a significant amount of RFI in the observations. For illustration in Fig.3 we presents dependence of the angular size of the Sun on frequency and time, calculated according with (1) using data obtained during one day of the observation on April 4. Raw output signals of the receivers used for these calculations were processed in no way. Obviously there are a large amount of interferences in the signal, especially at the lowest frequencies, that makes it possible to estimate only the tendency to increase a size with decreasing frequency. To obtain reliable results in such observations, it is necessary to develop algorithms for removal of RFI, for example, those used in URAN's receivers (Rashkovsky et al., 2012). This is especially true for the lowest part of the frequency range.

To process these noisy data, we chose areas with a bandwidth of about $1 \mathrm{MHz}$ and with duration of several

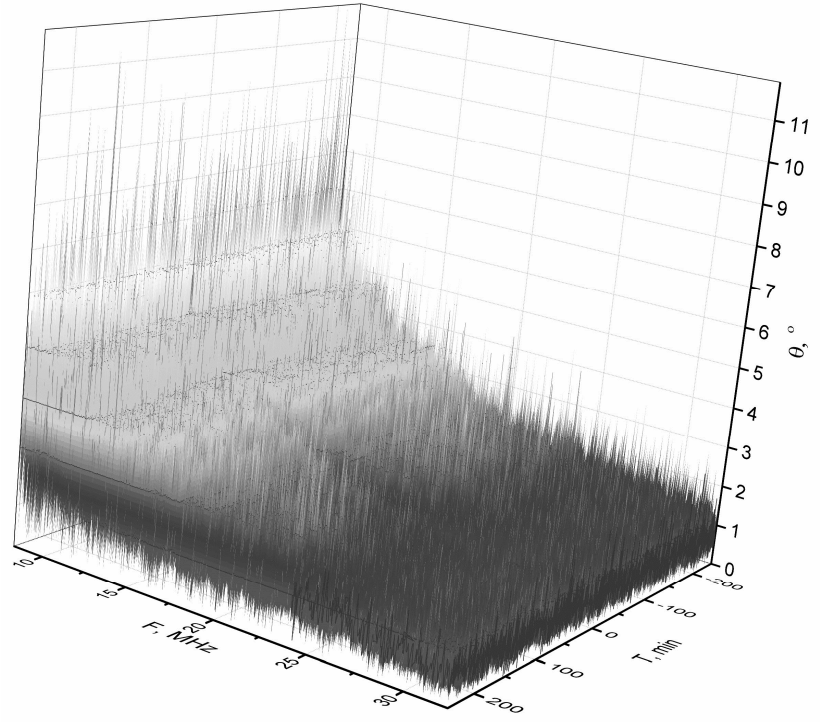

Figure 3: Angular size of the quiet Sun versus frequency and time

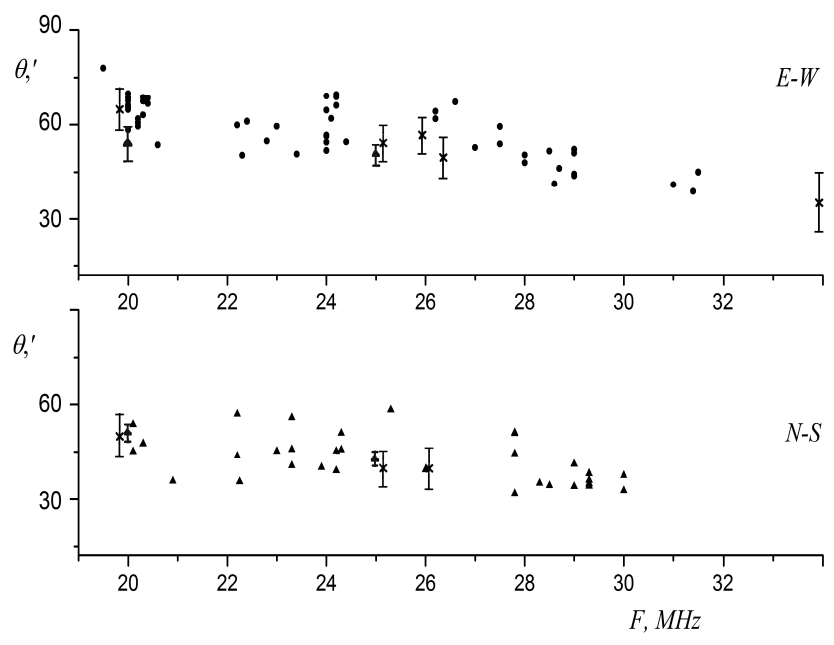

Figure 4: Dependence of angular sizes of the quiet Sun on frequency: a) equatorial diameter; b) polar diameter

minutes with relatively low level of the interferences. In such a frequency bandwidth the size of the quiet Sun can be considered constant and within a few minutes a modulation of a signal by the antenna pattern is rather low. In this timefrequency frame of the signal various methods of interference mitigation such as median filtering, threshold limitation, averaging were tested and their effect on a final result was evaluated. In our opinion, a combination of the median filter, which allows removing short in time or narrow frequency interference, followed by the threshold limitation which removes more extended interference was the most effective. Such an algorithm had a significant amount of manual processing, consisting in the frame selection and threshold finding, however it allowed making preliminary estimates of the angular diameter of the Sun in the equatorial and the polar direction, presented in Fig. 4.

In fig. $4 \mathrm{a}$ the dependence of the angular size of the quiet Sun on a frequency found with the east-west interferome- 
ters is shown. It represents the equatorial section of the source. In fig. $4 \mathrm{~b}$ the same dependence for polar section is shown. Mean value of a ratio of the polar diameter to the equatorial one is $\sim 0.75$. For comparison, the results obtained by Melnik et al. (2018) at frequencies of 20 and 25 $\mathrm{MHz}$ are shown by triangular marks with error bars, and data of Abranin and Bazelian (1986) at $25 \mathrm{MHz}$, Stanislavsky et al (2013) at 20 and $26 \mathrm{MHz}$, and Subramanian (2004) at $34.5 \mathrm{MHz}$ are indicated by crosses. Our data at frequencies below $20 \mathrm{MHz}$ obtained in these observations were not reliable enough, so they are not shown in Fig. 4.

\section{Conclusions}

Observations of radio emission of the quiet Sun with UTR-2 radio telescope in interferometric regime in the continuous frequency band of 8-32 $\mathrm{MHz}$ allowed obtaining the first preliminary results on solar sizes dependence on frequency in the east-west and north-south directions. Due to many ionosphere and artificial interferences, reliable results were obtained for frequencies from 20 to $32 \mathrm{MHz}$. However, the technique of data processing needs significant improvement for obtaining reliable results in all decameter range from 8 to $32 \mathrm{MHz}$. Using different sections of UTR-2 radio telescope as an interferometer showed good perspectives in finding sizes of the Sun at low frequencies in different periods of solar activity. This will allow to study some physical processes such as elementary processes of radiation, refraction, scattering and radio waves propagation in the solar corona at heights $0.5-2.5$ solar radii, which are in the base of radio emission of the quiet Sun. We hope also to determine the frequency dependence of brightness temperature of the Sun and answer the question if the radio emission of the Sun is blackbody or not.

\section{References}

Abranin E.P. and Bazelian L.L.: 1986, Preprint \#304, (in Russian), Kharkov, IRE NASU.

Aubier M., Leblanc Y.,Boischot A.: 1971, Astron. \& Astrophys., 12, 435.

Braude S.Ya., Megn A.V. Sodin L.G.: 1978, Antenny iss 26, (in Russian), Moskow, Sviaz

Megn A.V., Braude S.Ya., Rashkovsky S.L. et al.: 1997, Radiophys. and Radioastron. (in Russian), 2, 4, 385.

Melnik V.N., Shepelev V.A., Poedts S. et al.: 2018, Solar Phys., 293, 97.

Rashkovsky S.L., Belov A.S., Ivanov et al.: 2012, Radiophys. and Radioastron. ( in Russian), 17, 3, 207.

Stanislavsky A.A., Koval A.A., Konovalenko A.A: 2013, Astron. Nachr., 334, 10, 1086.

Subramanian K.R.: 2004, Astron. \&Astrophys., 426, 329.

Shepelev V.A.: 2015, Radiophys. and Radioastron. (in Russian), 20, 1, 20.

Zakharenko V., Konovalenko A.A., Zarka P. et al.: 2016, Astron. Instrum., 5, 4. 